LIST OF PREVIOUS PUBLICATIONS IN AJOE

EDITION 1 VOL 1 NO 1

John Lally \& Keith Cook

Sea Trek - A mechanism for working with youth at risk

Brian Nettleton

Transformational Moments in outdoor education

Sylvia Pilla \& David Tulip

A constructivist approach to environmental education

\section{EDITION 2 VOL 1 NO 2}

Martin Ringer

Passion and aliveness in outdoor leadership: leadership competencies from recreation to therapy

Terry Brown

Applying the adventure-react model

\section{Profile}

Lesley Pearce: A role model and inspiration

Research Brief

Pre-post abseil anxiety and perceptions of cliff difficulty

News Briefs

NORLD Board update

\section{EDITION 3 VOL 1 NO 3}

Peter Martin

New perspectives of self, nature and others

Geoff Cooper

The role of outdoor education in the 21st century

\section{Simon Priest}

Thoughts on managing directors in adventure programs

\section{EDITION 4 VOL 2 NO 1}

\section{A P Williams}

Outdoor education and physical education in the national curriculum (reprinted with acknowledgement to JAEOL (UK)

\section{Simon Crisp}

When does wilderness adventure become therapeutic? The need for broader frameworks: Experiential Reconstruction of developmental foundation

Bruce Hayllar \& Tracy Taylor

Outdoor management development: Changing an Organisation's culture

\section{Orbituary}

Professor John Sutton

\section{EDITION 5 VOL 2 NO 2}

Suzanne M Vincent

Emotional safety in adventure therapy programs: Can it be defined? Reprinted with permission from AEE Journal of Experiential Education

Tracey J Dickson

Processing the experience - Broadening the Vision

Peter McKenna \& Jackie Kiewa

The efficacy of journalism as a reflective tool

Jackie Kiewa \& Terry Brown

Profile of Dr Norm McIntyre

EDITION 6 VOL 2 NO 3

Jay Henderson

The role, history and future of an Australian journal of outdoor education

\section{Andrew Brookes}

First aid training for outdoor educators: The more the better?

Peter Holmes

Kids on Top II

Simon Crisp and Nicole Aunger

Wilderness-adventure therapy in adolescent psychiatry.

Simon Priest

Outdoor education in Norway

Nils Faarlund

Friluftsliv - a way home

\section{EDITION 7 VOL 3 NO 1}

James Neill \& Garry Richards

Does Outdoor Education Really Work? A Summary Of Recent Meta-Analyses

Ray Handley

Go Tell It On A Mountain ... And Let The Process Grow

Peter Martin

Education Ideology And Outdoor Leadership Education: Why ORCA And The AOEC Exist

Robyn Mulholland \& Antony Williams

Exploring Together Outdoors: A Family Therapy

Approach Based In The Outdoors For Troubled Mother

/ Daughter Relationships

Scott MacNaughton

Home From The Woods And Into The Doghouse

Robyn Edwards \& Tonia Gray

'Burnout' - What is it to you?

Simon Crisp \& Matt O'Donnell

Wilderness-Adventure Therapy In Adolescent Mental Health

Lesley Manfield \& James Pearse

A Way For A National Outdoor Leader Course

\section{EDITION 8 VOL 3 NO 2}

Brian Nettleton

The Metronomic Society And The Natural Environment

George W. Burns

Nature-Guided Therapy: A Case Example Of Ecopsychology In Clinical Practice

Sandy Gordon, Steve Houghton \& Julie Edwards

How People Change: Implications For Outdoor Educators

Carey J. Denholm \& Robert L. Sveen

If Only You Knew What I've Just Done": Adolescent Memories From A Tasmanian Wilderness Primary

Prevention Program

Mark Brackenreg

Learning From Our Mistakes - Before It Is Too Late

Ian Boyle \& Murray Toft

Traffic Light Decision Making

Graham Ellis-Smith

Rediscovering Our Indigenous Heart

Tracey Dickson

Client Change Analysis

Dell Brand and Mark Smith

Facilitator's Notebook - The Soft Skills Of Wilderness: Interacting Effectively With Delinquents 